\title{
Two new copepod species (Crustacea : Copepoda) from the Ohrid Lake
}

\author{
T.K. Petkovski ${ }^{\prime 1}$ \\ T. Karanovic 2,3
}

Keywords: taxonomy, Copepoda, Diacyclops, Bryocamptus, Ohrid Lake.

Two new copepod species are described from Lake Ohrid (Balkan peninsula). Diacyclops ichnusoides n.sp. (Cyclopoida, Cyclopidae) collected from interstitial waters on the lake coast, and it belongs to the "languidoides"-group. Bryocamptus $(R$.) mirus n.sp. (Harpacticoida, Canthocamptidae) lives in deep water and belongs to the "zschokkei"-group. With this investigation, the copepod list in Lake Ohrid increases to 36 species, of which 6 are endemic.

\section{Deux espèces nouvelles de Copépodes (Crustacea : Copepoda) du lac Ohrid}

Mots clés: taxonomie, Copepoda, Diacyclops, Bryocamptus, lac Ohrid.

Deux espèces nouvelles de Copépodes du lac Ohrid (péninsule des Balkans) sont décrites. Diacyclops ichnusoides n.sp. (Cyclopoida, Cyclopidae) récoltée dans les eaux interstitielles de la rive du lac, appartient au groupe "languidoides". Bryocamptus (R.) mirus n.sp. (Harpacticoida, Canthocamptidae), qui fait partie du groupe "zschokkei" vit dans les eaux profondes. A ce jour, 36 espèces de Copépodes ont été recensées dans de lac Ohrid, six d'entre elles sont endémiques.

\section{Introduction}

Ohrid Lake is located in the central part of the Balkan Peninsula, between $40^{\circ} 54^{\prime}$ and $41^{\circ} 10^{\prime} \mathrm{N}$, and between $20^{\circ} 38^{\prime}$ and $20^{\circ} 49^{\prime} \mathrm{E}$. Its area is about 349 square kilometres, the maximal depth is 286 meters, while the average depth is about 145 meters (Stankovic 1989). Ohrid Lake is a tectonic lake, situated in the karst region. It is one of the oldest lakes in Europe, with very wealty and, also, endemic fauna.

The copepod fauna of the Ohrid Lake was not investigated systematically, but there are a lot of data given by Kiefer (1932, 1937a, 1937b), Chappuis (1936a, 1936b, 1937), Brehm (1939), Petkovski (1954, 1955,

1. Macedonian Museum of Natural History, Bulevar Ilinden 86 , 91000 Skopje 55, Macedonia.

2. University of Montenegro, Faculty of Sciences, Department of Biology, P.O.Box 307, 81000 Podgorica, Yugoslavia.

3. Correspondent author.
1956, 1964, 1983, 1984), Herbst (1957) and Einsle (1971, 1975). Till now 32 copepod species are known from the Ohrid Lake, of which 4 ones are endemic.

Analysing some samples, collected in 1987 and 1988, we found two new copepod species. Also, were found two species which are new for the Ohrid Lake: Bryocamptus (s.str.) minutus (Claus, 1863) and Bryocamptus (L.) echinatus (Mrazek, 1893).

\section{Methods}

The samples were taken with Karaman-Chappuis method (from the interstitial waters, on the lake coast), or with a benthic net (for the pelagic ones, on a depth of 40-60 meters), and fixed by several drops of $36 \%$ formaldehyde. They were washed and copepods were sorted with a stereoscopic binocular Wild-M5 and removed into $70 \%$ ethyl alcohol. The specimens were dissected in a mixture of distilled water and glycerol (1:1) with fine entomological needles. Dissected appendages were removed on a slide (also in a mixture of water and glycerol) and covered with a coverslip. For the larger parts (abdomen, etc.) two hairs between the 
slide and the coverslip were used, so the parts could not be smashed.

Dissected appendages were examined and figured using a binocular microscope Wild-M20 with drawing-tube attachment, and were preserved in Faure's medium. Specimens not dissected, also were examined with a microscope, in a mixture of water and glycerol, and after that removed in $70 \%$ ethyl alcohol, where they are preserved.

In the descriptions were used standard abbrevations of the characters: Gsg - genital segment; Fu - furca; Ro - rostrum; A1 - antennula; A2 - antenna; Md - mandible; Mxl - maxillula; Mx - maxilla; Mxp - maxillipede; P1 - first leg; P2 - second leg; ...; P6 - sixth leg; Enp - endopodite; Exp - exopodite; Enp2P3 - second endopodite article of third leg.

\section{Results}

\subsection{List of copepod species}

With this investigation the list of copepod species in Ohrid Lake counts 36 species or taxa: We give the list of all known copepod species from the Ohrid Lake, where the endemic species are marked with an asterisk.

1. Eudiaptomus gracilis (Sars, 1863)

2. Arctodiaptomus (A.) steindachneri (Richard, 1897)

3. Arctodiaptomus (A.) stephanidesi (Pesta, 1935)

4. Macrocyclops albidus (Jurine, 1820)

5. Eucyclops (E.) serrulatus (Fischer, 1851)

6. Eucyclops (E.) speratus (Lilljeborg, 1901)

7. Eucyclops (E.) macruroides (Lilljeborg, 1901)

* 8. Eucyclops (E.) porrectus Kiefer, 1932

* 9. Ochridacyclops arndti Kiefer, 1937

10. Paracyclops fimbriatus (Fischer, 1853)

*11. Cyclops ochridanus Kiefer, 1932

12. Megacyclops viridis (Jurine, 1820)

13. Diacyclops bicuspidatus (Claus, 1857)

14. Diacyclops bisetosus (Rehberg, 1880)

15. Diacyclops languidus (Sars, 1863)

16. Diacyclops hypnicola (Gurney, 1927)

17. Diacyclops $\mathrm{cf}$. languidoides

*18. Diacyclops ichnusoides n.sp.

19. Mesocyclops leuckarti (Claus, 1857)

20. Thermocyclops dybowskii (Lande, 1890)

21. Cryptocyclops bicolor (Sars, 1863)
22. Ectinosoma abrau (Kritschagin, 1877)

23. Nitokra hibernica (Brady, 1880)

24. Attheyella (A.) crassa (Sars, 1863)

25. Attheyella (A.) wierzejskii (Mrazek, 1893)

26. Moraria sp.

27. Ceuthonectes serbicus Chappuis, 1924

28. Bryocamptus (B.) minutus (Claus, 1863)

29. Bryocamptus (R.) zschokkei (Schmeil, 1893)

30. Bryocamptus $(R$.) pygmaeus (Sars, 1863)

*31. Bryocamptus $(R$.) mirus n.sp.

32. Bryocamptus (L.) dacicus (Chappuis, 1923)

33. Bryocamptus (L.) echinatus (Mrazek, 1893)

34. Elaphoidella elaphoides (Chappuis, 1923)

*35. Elaphoidella bulbifera Chappuis, 1937

36. Paracamptus schmeili (Mrazek, 1893)

\subsection{Diacyclops ichnusoides n.sp.}

\subsubsection{Type material}

One female (Holotype) and one male (Allotype), from the interstitial waters in the NW coast of the Ohrid Lake, near the village Gorica, collected the 2th November 1988 , by T.Petkovski. Both specimens are deposited in the Department of Biology, Faculty of Sciences, University of Montenegro.

\subsubsection{Description}

\section{FEMALE (Holotype)}

Length, including furcal rami (excluded furcal setae) is $0.36 \mathrm{~mm}$. Nauplius eye absent. Hind margin of each body segment smooth and without rows of spines. Only anal segment with a row of spinules ventrally and laterally, at base of furcal rami. Anal operculum very short and broad (Fig. 8). Genital segment about 1.18 times as width as long, and very large in comparison with the rest of abdomen (Fig.1). Receptaculum seminis situated in the first half of genital segment, bipartite, and first part larger than second. On the middle of genital segment, ventrally, there is an arch chitinous suture with receptaculum's aperture on the middle. Furcal rami parallel, close, and about 1.94 times longer than wide: Apical setae with following proportion of lengths (from outside to inside): $1 / 5.3 / 9.3 / 0.76$. Outer apical seta very strong, spiniform (Fig.1). Dorsal seta as long as furcal ramus, and attached at distal 1/4 of furcal length. Furcal rami with a transverse row of spines dorsally, which is unique in the genus Diacyclops (Fig.8). A1 11-segmented, almost reaching the end of cephalothoracic somite (Fig.11). A2 4-segmented, with well-developed exopodite seta, and three 


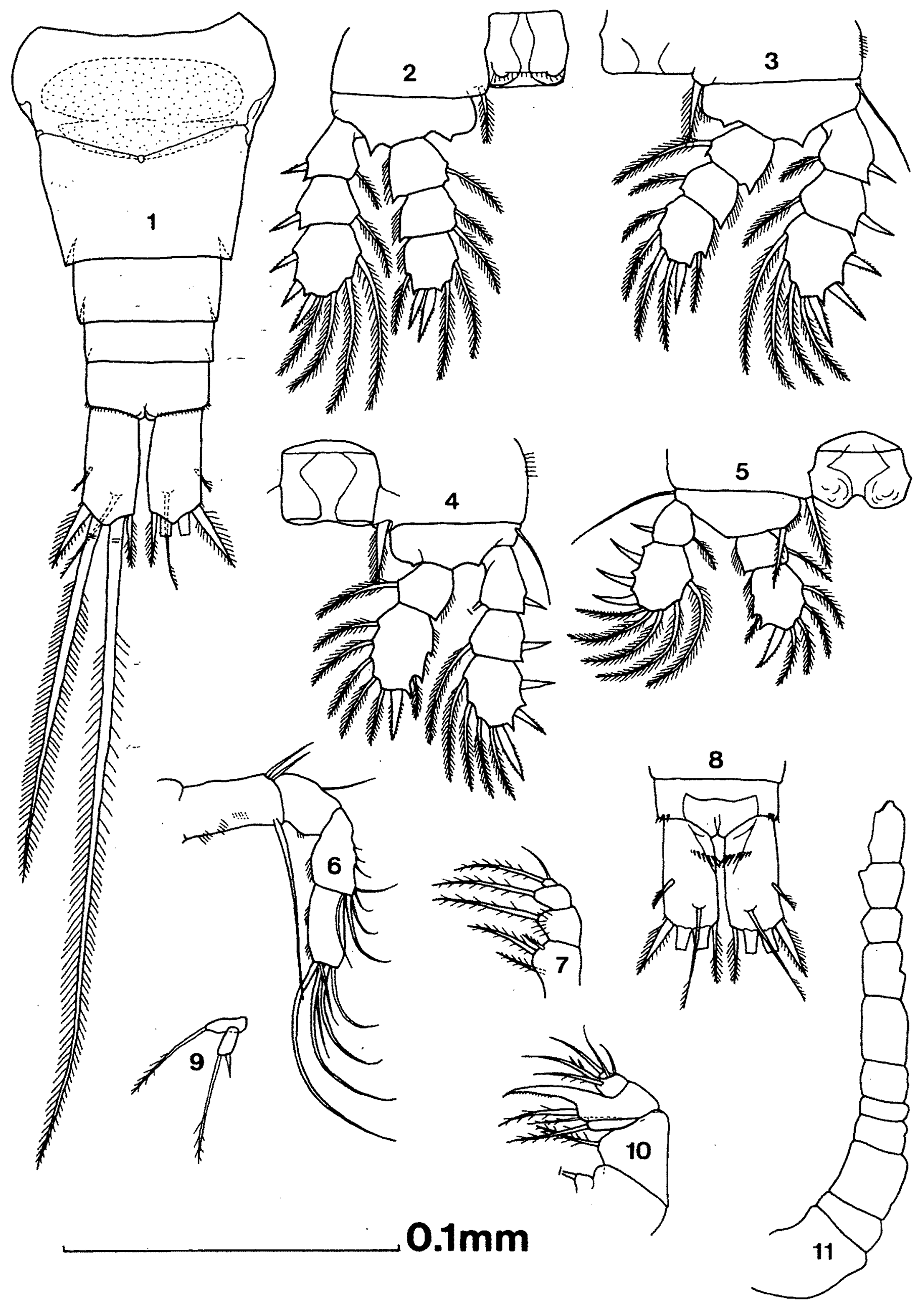

Figs. 1-11. Diacyclops ichnusoides n.sp., holotype (female 0.36mm): 1 - abdomen ventral; 2 - P4; 3 - P3; 4 - P2; 5 - P1; 6 - A2; 7 - Mxp; 8 - Fu dorsal; 9 - P5; $10-\mathrm{Mx} ; 11-\mathrm{Al}$.

Figs. 1-11. Diacyclops ichnusoides n.sp.,holotype (femelle 0,36 mm). 


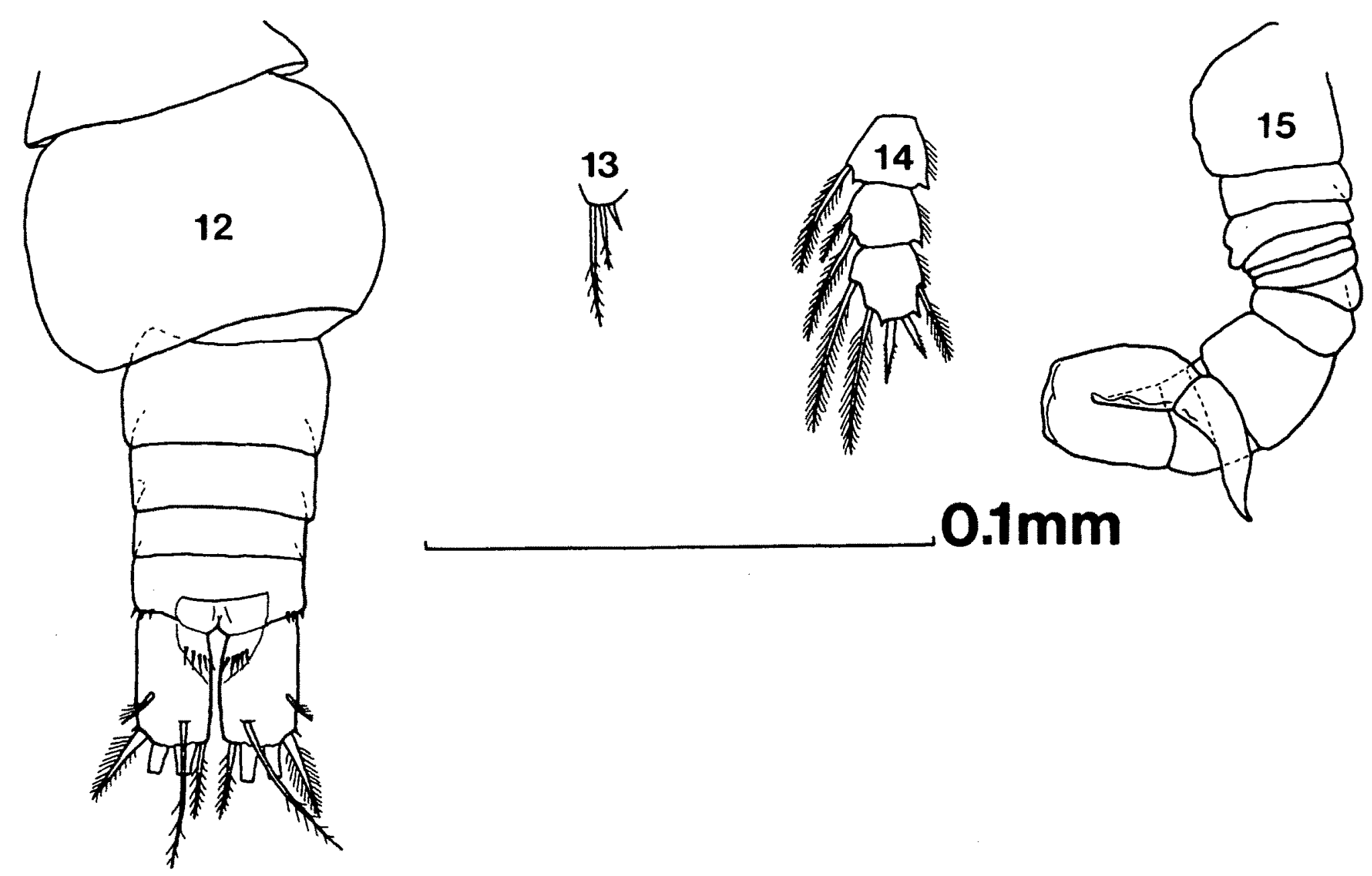

Figs. 12-15. Diacyclops ichnusoides n.sp., allotype (male $0.336 \mathrm{~mm}$ ): 12 - abdomen dorsal; 13 - P6; 14 - EnpP4; 15 - A1.

Figs. 12-15. Diacyclops ichnusoides n.sp., allotype (mâle 0,336 mm).

groups of hairs on the first segment (Fig.6). Maxilla shown in Fig.10. Mxp 4-segmented, with reduced number of setae ( 7 instead of 9) (Fig.7). Articulation formula of swimming legs distinctive for "languidoides"-group (exp/enp): $2 / 2 ; 3 / 2 ; 3 / 3 ; 3 / 3$. Spine formula of exopodites P1-P4: 3.3.3.3; setal formula: 5.4.4.4. Enp3P4 approximately as long as width, with two apical spines of which the inner one is about 1.29 times longer than the outer, and as long as article. $\mathrm{Ou}-$ ter seta reaching the tip of outer spine, while inner setae are much longer. Intercoxal plates with distinctive features (Figs. 2, 3, 4, 5), and only that on fourth leg with a transverse row of spinules. P5 with very short and laterally bulging basal article (Fig.9). Distal article about 2 times longer than wide and subapically bearing spine, which is a little shorter than article. P6 very reduced, like one short seta, and visible on the laterodorsal surface of Gsg above genital apertures.

MALE (Allotype)

Body length is $0.336 \mathrm{~mm}$. A2, mouth parts, swimming legs and P5 are similar to those of female. Gsg very large in comparison with the rest of abdomen (Fig.12). Furcal rami shorter than females (index length/width is 1.7), and bearing a little longer dorsal setae (Fig.12). A1 geniculate (Fig. 15). P6 bearing three setae with following proportion of lengths (from inside to outside): 1/2.4/4 (Fig.13).

\subsubsection{Ecology}

Colourless body, absence of nauplius eye, very short swimming legs, small body, and locality where material was collected lead to the conclusion that $D$. ichnusoides $\mathrm{n} . \mathrm{sp}$. is a real troglobiont, living in the interstitial waters: Small number of specimens is probably consequence of rising waters in interstitial habitats in the autumn, and of numerous specimens of trogloxen or troglophil species that possible prey $D$. ichnusoides is.

\subsubsection{Distribution}

Known only from type locality. Probably endemic species of interstitial waters in the Ohrid Lake drainage area. 


\subsubsection{Etymology}

The species is named ichnusoides after $D$. ichnusae Pesce \& Galassi, 1985, because of their great similarity.

\subsubsection{Remarks and affinities}

D. ichnusoides n.sp. belongs to the "languidoides"group. Its very short furcal rami and other morphological details makes it the most similar to Diacyclops ichnusae Pesce \& Galassi 1985, which was described from subterranean waters of Sardinia (Pesce \& Galassi 1985). However, it is evidently distinguishable from the latter by the combination of the following characters: 1) exopodite seta on A2 present; 2) furcal rami with a transverse row of spines dorsally; 3 ) dorsal seta on furcal ramus shorter.

$D$. ichnusoides has shorter furcal rami even than $D$. ichnusae. Their index (length/width) at $D$. ichnusae is 2.09-2.1, while at $D$. ichnusoides it is 1.94 (at females). More shorter furcal rami has Diacyclops improcercus (Mazepova, 1950) comb. nov., which was described from the Baykal Lake (Mazepova 1950). This Baykal species differs from $D$. ichnusoides as follows: 1) nauplius eye present; 2) no spines on dorsal surface of furcal rami; 3) subapically spine on distal article of P5 longer than article; 4) inner and outer apical setae on furcal ramus longer than ramus. Many other morphological details were not given in the original description of D. improcercus (A2, Mxp, P1-P4), so they could not be compared.

There are some similarities between $D$. ichnusoides and D. hypnicola (Gurney, 1927), but these two species are distinguishable by many characters (Fu, Gsg, Mxp, Mx, CoxaP4, and body length - D. hypnicola is almost twice as long as $D$. ichnusoides). Also, these two species were found together, which is the best indication of their specific isolation.

\subsubsection{Accompanied species}

Together with $D$. ichnusoides $n$.sp. we found the following species:

1. Diacyclops hypnicola - 2 females;

2. Mesocyclops leuckarti - 1 male, 2 females and 64 copepodids;

3. Nitokra hibernica - 3 males and 36 females ( 26 ovigerous);

4. Attheyella (s.str.) wierzejskii - 1 male;

5. Bryocamptus (s.str.) minutus - 1 ovigerous female;

6. Elaphoidella elaphoides - 11 males and $39 \mathrm{fe}$ males (18 ovigerous).

\subsection{Bryocamptus (Rheocamptus) mirus n.sp.}

\subsubsection{Type material}

Holotype (ovigerous female, $0.67 \mathrm{~mm}$ ), allotype (male) and 7 paratypes (6 ovigerous females +1 female), from the NW part of Ohrid Lake (on depth of 4060 meters), 16 October 1987, collected by T.Petkovski. All specimens are deposited in the Department of Biology, Faculty of Sciences, University of Montenegro. Holotype, Allotype and 2 Paratypes were dissected and mounted on a slide in Faure's medium. Other Paratypes were placed in a glass test tube in $70 \%$ ethyl alcohol.

\subsubsection{Description}

Female (holotype). Length, including furcal rami (excluded furcal setae) is $0.67 \mathrm{~mm}$. Rostrum small, even wellrounded. Hind margin of each body somite smooth. Genital segment with a few spines on the hind margin laterally. Genital field with characteristic pattern (Fig.16). Ovisac with 15 eggs. Second abdominal segment armed ventrolaterally with transverse row of spines. Third segment with an uninterrupted row of spines on lateral and ventral hind margins. Anal segment armed laterally (at the base of the furcal rami) with 5 small spines (Fig. 24). Anal operculum completely smooth, concave, and rather short (Fig.18). Furcal rami divergent, about 1.7 times as long as width and even narrowed (Fig.16). Armature consists of two lateral setae (each with two spines on the base) (Fig.24), one dorsal and three apical setae. On the base of the apical setae ventrally, there are another two spines. Dorsal seta attached behind well-developed chitinous ridge, at the middle of furcal length (Fig.18). Inner apical seta little longer than caudal ramus, somewhat moved on ventral side, and bent to inside. Middle apical seta little longer than abdomen ( 1.08 times), and about 1.7 times longer than outer apical seta (Fig.18). A1 8segmented, with a big esthete on fourth segment, reaching beyond the top of $\mathrm{A} 1$ for a length of distal segment (Fig. 23). A2 3-segmented, with 2-segmented exopodite which is armed with 4 setae (Fig. 19). Md palp 2-segmented. First segment bearing one subapical seta, second armed with one lateral and four apical setae. Maxillipeda shown in Fig. 26. All swimming legs with 3-segmented exopodites and 2-segmented endopodites. The setal/spine formula of swimming legs:

$\begin{array}{lcc} & \text { Exp } & \text { Enp } \\ \text { P1 } & 0 / 1 / 1.1 .2 & 1 / 1.2 .0 \\ \text { P2 } & 0 / 1 / 1.2 .3 & 1 / 2.2 .1 \\ \text { P3 } & 0 / 1 / 2.2 .3 & 1 / 4.1 .1 \\ \text { P4 } & 0 / 1 / 2.2 .3 & 1 / 2.2 .1\end{array}$




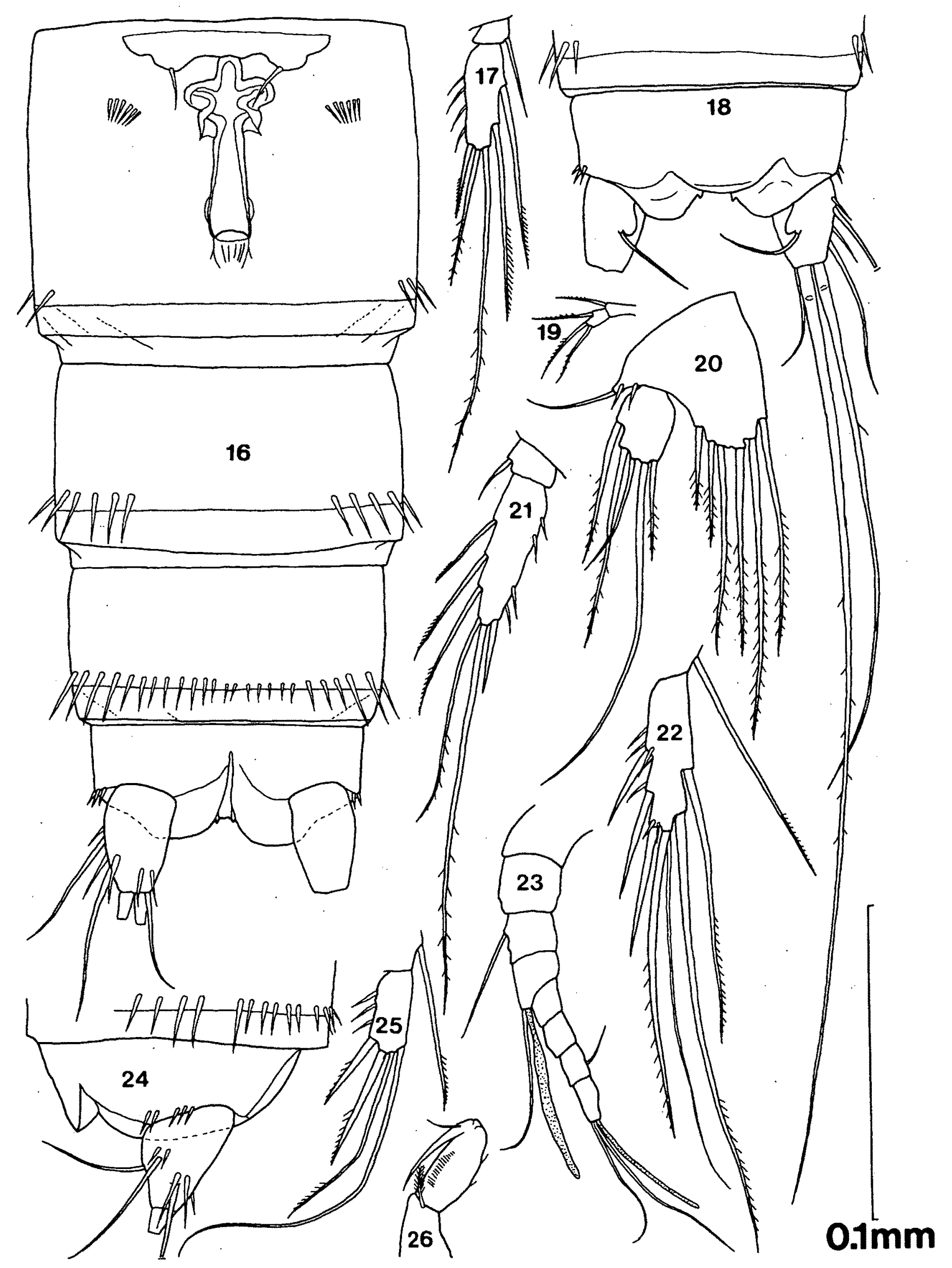

Figs. 16-26. Bryocamptus (R.) mirus n.sp., holotype (female $0.67 \mathrm{~mm}$ ); 16 - abdomen ventral; 17 - EnpP4; 18 - Fu dorsal; 19 - ExpA2; 20 - P5; 21 - EnpP3; 22 - Exp3P4; 23 - A1; 24 - Fu lateral; 25 - Exp3P1; 26 - Mxp.

Figs. 16-26. Bryocamptus (R.) mirus n.sp., holotype (femelle $0,67 \mathrm{~mm}$ ). 
Exp2P1 bearing very strong inner seta, which considerably reaches beyond the top of distal segment (Fig. 25). P5 bearing 6 setae on distal margin of basiendopodite, and second one (from inner side) is longest. First, third and fourth setae align with tips (Fig. 20). On the lateral side of basiendopodite, at the base of epipodite seta, there are only two spines. Exopodite of P5 about 1.36 times as long as width and armed with 5 setae.

\section{MALE (Allotype)}

Body length is $0.56 \mathrm{~mm}$. Genital segment armed with two hairs only, dorsolaterally. Second and third abdominal segments armed with a transverse row of spines laterally and ventrally, which are interrupted by little spaces at middle part on ventral side (Fig.27). Fourth abdominal segment with uninterrupted row of spines on lateral and ventral side. Anal segment armed laterally with 5 small spines, at the base of furcal rami (like a female), and ventrally with an arch row of 6 spines. Anal operculum similar to female's, completely smooth (Fig.29). Furcal rami similar to female's, just a little shorter, and bearing proportionally longer setae. A1 prehensile, bearing very long esthete (Fig. 30). A2, mouth parts, P1, P2, ExpP3 and ExpP4 similar to female's. EnpP3 characteristically modified and bearing two unequal apical setae on distal segment (Fig.28). EnpP4 2-segmented. First segment small and unarmed, second one armed with 4 or 5 setae (Fig.31). P5 bearing 6 setae on the distal margin of basiendopodite, like a female's, but they are much shorter and stronger than female's (Fig.27). Distal margin of basiendopodite less extended. Exopodite of P5 armed with 6 setae and one hair on the outer margin. P6 consisting of a chitinous lamella, bearing 3 setae. Inner and outer setae of this appendage are equal, whereas the middle one is much shorter (Fig.27).

\subsubsection{Variability}

Sole qualitative form of variability was recorded on male's Enp2P4, bearing 4 or 5 setae (Fig.31). All females were very uniform, even their body lengths were similar (from 0.65 to $0.68 \mathrm{~mm}$ ). It is very important that all females had completely smooth anal operculum and indentical form of P5.

\subsubsection{Ecology}

The species was collected in a lake profundal at a depth of 40-60 meters. On the bodies of the most specimens it was found a few epizootic solitary Peritricha (Protozoa, Ciliata). Six of seven females were with ovisacs (16 eggs, on the average), what means that $B$. $(R)$ mirus was in the mating season at October.

\subsubsection{Distribution}

Known only from the type locality. Probably endemic species of the Ohrid Lake.

\subsubsection{Etymology}

The species in named after the Roman adjective mirus (what means eccentric), because of the very strange form of the male's P5.

\subsubsection{Remarks and affinities}

Bryocamptus $(R$.) mirus n.sp. is most similar to the holarctic species Bryocamptus (R.) zschokkei (Schmeil, 1893). Many morphological details, especially on swimming legs, are almost identical in the both species. However, $B$. mirus is evidently distinguishable from $B$. zschokkei as follows:

Female: 1) anal operculum completely smooth, 2) longest seta on distal margin of basiendopodite P5 is second one (fourth in B. zschokkei), 3) armature on abdominal segments quite reduced;

Male: 1) anal operculum smooth, 2) Enp2P2 bearing one spiniform seta on outer margin, 3) basiendopodite of P5 with 6 setae.

Bryocamptus (R.) gauthieri (Roy, 1924) has also a smooth anal operculum (only at female). This species is distributed in North Africa (Lang 1948), but it differs from $B$. mirus by many features (especially in swimming legs). Many other species in the genus Bryocamptus have a smooth anal operculum, especially those in the subgenus Limocamptus from the Baykal Lake (Borutzky 1952). It means that this feature is secondary and it was generated convergently.

But the basiendopodite of male's P5 with 6 setae is very strange and unknown in the genus Bryocamptus till now. It resembles to hermaphroditism, but all other secondary sexual features (Gsg, A1, EnpP3, EnpP4, P6) are completely normal for a male from the subgenus Rheocamptus. On the other side, there is a very small probability that this feature is secondary, because of all other morphological features are very similar to those of $B$. zschokkei. Probably the basiendopodite of male's P5 with 6 setae is an atavism, but a correct answer will be known only after examinations on big. ger series of specimens.

\subsubsection{Accompanied species}

In the same sample the following species were found together with $B$. (R.) mirus n.sp.:

1. Paracyclops fimbriatus - 2 females;

2. Ectinosoma abrau - 6 ovigerous females and 21 copepodids; 


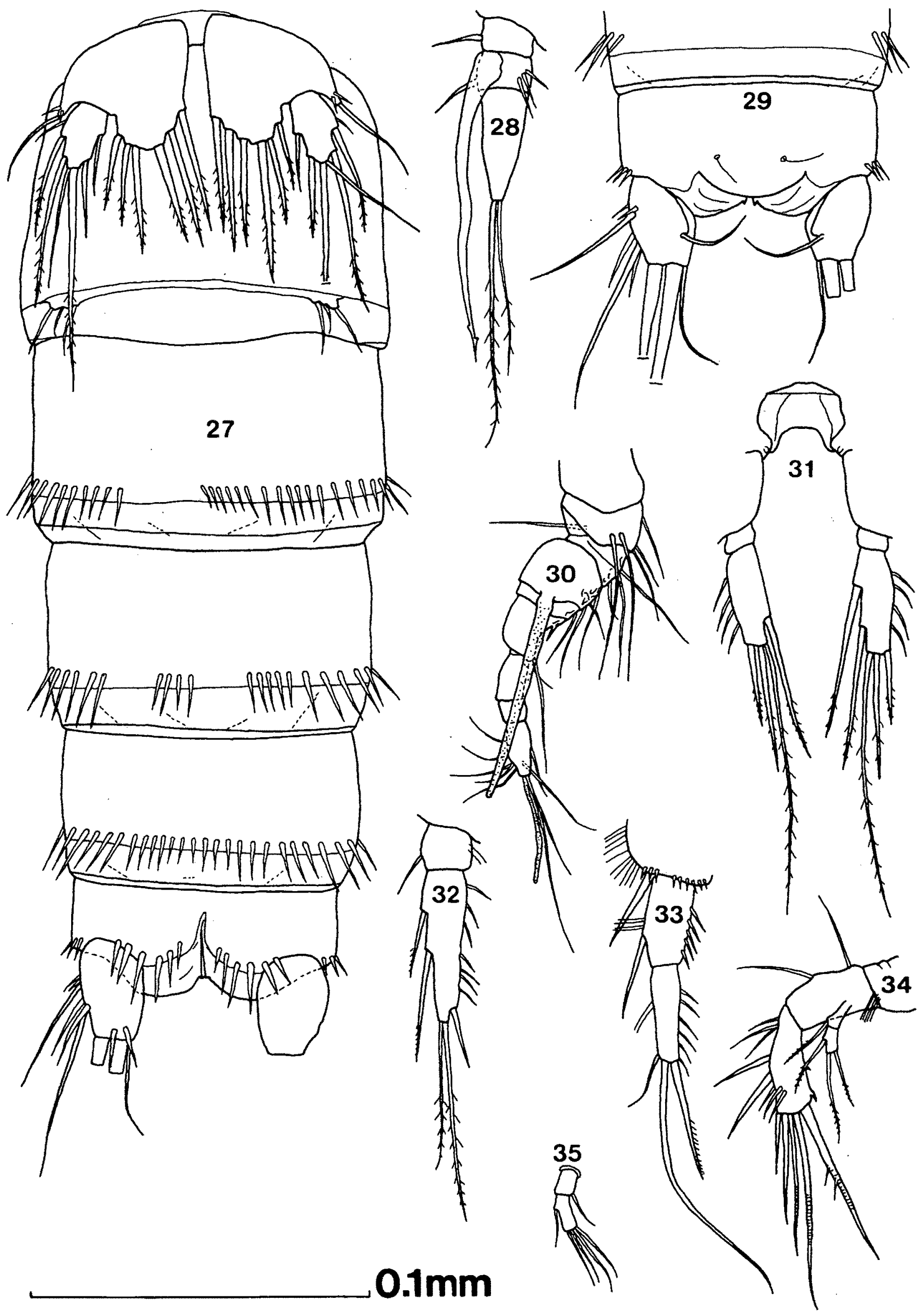

Figs. 27-35. Bryocamptus (R.) mirus n.sp., allotype (male $0.56 \mathrm{~mm}$ ): 27 - abdomen ventral; 28 EnpP3; 29 - Fu dorsal; 30 - A1; 31 - EnpP4; 32 EnpP2; 33 - EnpP1; 34 - A2; 35 - Md palp.

Figs. 27-35. Bryocamptus (R.) mirus n.sp., allotype (mâle $0,56 \mathrm{~mm}$ ). 
3. Attheyella (s.str.) wierzejskii - 8 males, 19 females ( 8 ovigerous) and 8 copepodids;

4. Bryocamptus (Limocamptus) echinatus - 5 males, 21 ovigerous females and 6 copepodids.

\section{References}

Borutzky E.W. 1952. - Rakoobraznie, Harpacticoida presnih vod. Fauna SSSR, 3(4): 422 p.

Brehm V. 1939. - Entomostraken aus dem albanisch-jugoslawischen Grenzgebiet. Zool. Anz., 127 (1/2): 25-38.

Chappuis P.A. 1936a. - Über Höhlencopepoden. Bull. Soc. Sci. Cluj, 8: 321-334.

Chappuis P.A. 1936b. - Subterrane Harpacticiden aus Jugoslavien. Bull. Soc. Sci. Cluj, 8: 386-398.

Chappuis P.A. 1937. - Weitere subterrane Harpacticoiden aus Jugoslavien. Bull. Soc. Sci. Cluj, 8: 503-532.

Einsle U. 1971. - Einige Arten der Gattung Cyclops s.str. aus Jugoslawien. Fragmenta Balcanica, 8(9): 61-74.

Einsle U. 1975. - Revision der Gattung Cyclops s.str. speziell der Abyssorum-gruppe. Mem. Ist. Ital. Idrobiol., 32: 57-219.

Herbst H.V. 1957. - Zoological Results of a Collecting Journey to Yugoslavia, 1954, 5. - Cyclopoida Gnathosoma (Crustacea Copepoda). Beaufortia, 65(5): 223-240.

Kiefer F. 1932. - Neue Süsswassercopepoden aus Jugoslawien, I. Cyclopiden. Zool. Anz., 101(3/4): 49-60.

Kiefer F. 1937a. - Die freilebender Ruderfusskrebse (Crustacea Copepoda) Jugoslawiens. Bull. Soc. Sci. Skopje, 18: 77-105.
Kiefer F. 1937b. - Ein neuer Cyclopide (Crust. Copepoda) aus dem Ochridsee. Zool. Anz., 120(7/8): 137-143.

Lang K. 1948. - Monographie der Harpacticiden, II. Lund: 899 1682.

Mazepova G.F. 1950. - Novie vidi Ciklopov iz ozera Bajkal. Dokladi Akademii Nauk SSSR, 74(6): 865-868.

Pesce G.L. \& Galassi D.P. 1985. - Due nuovi Diacyclops del complesso languidoides" (Copepoda, Cyclopoida) di acque sotterranee di Sardegna e considerazioni sul significato evolutio dell'antenna nei Copepodi stigobionti. Boll. Mus. civ. St. nat. Verona, 12: 411-418.

Petkovski T.K. 1954. - Beitrag zur Kenntnis der Jugoslavischen Cyclopiden. Acta Mus. Macedonici Sc. Nat., 2(4): 1-31.

Petkovski T.K. 1955. - IV Beitrag zur Kenntnis der Copepoden. Acta Mus. Macedonici Sc. Nat., 3(3): 71-104.

Petkovski T.K. 1956. - Über einige Copepoden aus Hohlen- und Grundgewässem Jugoslaviens. Izdanija Inst. Piscic. Macedonici, 1(8): 185-208.

Petkovski T.K. 1964. - Bemerkenswerte Entomostraken aus Jugoslavien. Acta Mus. Macedonici Sc. Nat., 9(7): 147-182.

Petkovski T.K. 1983. - Faune de Macedoine, 5 Calanoides - Calanoida (Crustacea - Copepoda). Mus. d'Hist. Nat. de la Macedoine, Skopje: $182 p$.

Petkovski T.K. 1984. - Bemerkenswerte Cyclopiden (Crustacea, Copepoda) aus den subterranen Gewässern Sloweniens. Acta Mus. Macedonici Sc. Nat., 17(2): 23-52.

Stankovic S.M. 1989. - Lakes of Yugoslavia. Strucna knjiga, Belgrade: $281 \mathrm{p}$. 